\title{
Insurance of Financial Risks of Industrial Enterprises
}

\author{
Donetskova Olga \\ Department of banking and insurance \\ Orenburg state University \\ Orenburg, Russia \\ Olja-ja-77@mail.ru
}

\author{
Sadykova Lucia \\ Department of banking and insurance \\ Orenburg state University \\ Orenburg, Russia \\ Sad.1.m@mail.ru
}

\author{
Korobeynikova Elena \\ Department national and world economy \\ Federal state budgetary educational institution of higher education \\ Samara state technical University \\ Samara, Russia \\ Korob-lena79@rambler.ru
}

\begin{abstract}
The article discusses the theoretical and practical aspects of the development of the market for insurance of financial risks of industrial enterprises. Theoretical studies have revealed that the total insurance protection of industrial enterprises is represented by property insurance, business risk insurance, civil liability insurance and personal insurance. In their research, the authors turned to foreign sources and studied the features of insurance of industrial enterprises abroad. In foreign practice, these areas of insurance have become widespread, but in Russian practice they are never used. However, the authors have identified a narrow list of insured financial risks of industrial enterprises in Russia. In Russia today, only insurance in case of production stoppage has become widespread. The authors attempt to consider one of the poorly developed insurance industries in Russia, as insurance of financial risks of industrial enterprises, to show the problems of this insurance industry and determine ways to solve them. The analysis showed that the leader of the insurance market in terms of collected premiums is property insurance. Premiums for financial risk insurance are increasing due to the growth of bank card insurance. The authors, when studying large and mediumsized businesses, found that large enterprises use business insurance, avoiding gray "salary" schemes and cover a large amount of various risks. However, some companies use "double" accounting in their practice, which makes it difficult for insurers to determine the real level of risk of their business. The small number of insurance companies and the unwillingness of insurers to provide financial risk insurance services for industrial enterprises are the main problems today. The authors propose to adopt standard insurance rules in this area.
\end{abstract}

Keywords: insurance market, industrial enterprises, financial risks, optional insurance

\section{INTRODUCTION}

Risk occurs in our lives all the time and it has a certain impact on the results of our activities, on the decisions we have made. At present, almost all of the industrial enterprises are exposed to risks. The necessity of the risk management is caused by the complex inwardness of their manifestations in industrial enterprises. In addition, financial crises have recently become more frequent, causing financial risks, the probability of which was not previously fully considered. All of it indicates the necessity to explore the financial risks of industrial enterprises and their insurance. The relevance of this topic is about an insufficient use of financial risks insurance in industrial enterprises of Russian insurance companies.

\section{LiteraRAture REVIEW AND RESEARCH METHODS}

Despite the interest to the topic, insurance companies are just beginning to show interest in financial products in modern science.

Many authors discuss the problems of this topic. E. Karanina considers not only the financial risk management, its strategic concepts and models but also defines professional standards. The basic methods of financial risks assessment and their specificity researched by L. Kurbanayeva[1]. N. Khokhlov considers risk management, including risks of industrial enterprises [2]. O. Donetskova discusses the problems associated with the development of insurance business in Russia. The author emphasizes the importance of insurance business in terms of time conditions and defines the modern features of it in Russia. Karanina E. V. research financial risk management: studyes strategic concepts, models, professional standards [3]. The formation of an insurance protection system in industrial enterprises is an important 
TABLE I. VOLUME OF INSURANCE PREMIUMS FOR 2016-2018 [9]

factor that studies N. V. Nemtsova [4]. some authors touch upon the organizational model of regional socio-economic territorial management [5].

However, many aspects remain undisclosed and require further study and revision.

The methodology of the article includes General scientific research methods, methods of system analysis and synthesis, methods of statistical data analysis.

\section{RESULTS OF THE RESEARCH}

Financial risks of industrial enterprises are sets of types of insurance, provided for the obligations of the insurer on insurance payments, in the amount of full or partial compensation for loss of income (additional costs) caused by the following: production stoppage or reduction of production (as a result of specified events); loss of employment; unforeseen expenses (contingencies); legal expenses (costs) incurred by the insured person and others. [6].

Insurance of industrial enterprises financial risks is aimed at:

1) provisions for losses caused by the necessity of restoring fixed and working capital lost or damaged as a result of various adverse events;

2) covering damages connected with interruptions in production activity and also with implementation by the enterprise of commercial activity;

3) compensation of the harm caused by the enterprise to the third parties at implementation of the activity;

4) provision of insurance payments to workers and employees of the enterprise in the event of lost ability to work, as well as to compensate the costs for the restoration of health [7].

The total insurance coverage of industrial enterprises includes property, business risk, civil liability and personal insurance. It could be noticed, that the list of insured financial risks of industrial enterprises is not wide enough for Russian conditions and many of these types of insurance have never been used in practice. A certain spread in our country has received insurance in case of Production stoppage [8]. Although, analysts express the opinion that in the future there will be development not only in the segment of insurance against losses in production but also insurance of losses due to breach of contractual obligations by contractors, insurance of lease payments, of professional liability leading to financial losses and investment insurance. We find it necessary to consider the volume of insurance premiums and payments for insurance of financial risks (see table 1,2).

In total, during the analyzed period insurers collected an average of 27.1 billion rubles of premiums for this type of insurance. The share of financial risk insurance in the total insurance structure is on average 1.3 percent. According to the Table I, the share of business risk insurance in 2018 increased by only 0.2 percent compared to 2016 .

\begin{tabular}{|c|c|c|c|c|c|c|}
\hline \multirow{2}{*}{$\begin{array}{l}\text { Types of } \\
\text { insurance }\end{array}$} & \multicolumn{2}{|c|}{2016} & \multicolumn{2}{|c|}{2017} & \multicolumn{2}{|c|}{2018} \\
\hline & $\begin{array}{l}\text { billion } \\
\text { rubles }\end{array}$ & $\begin{array}{c}\text { \% of } \\
\text { total } \\
\text { billio } \\
n \\
\text { ruble } \\
s\end{array}$ & $\begin{array}{l}\text { billion } \\
\text { rubles }\end{array}$ & $\begin{array}{c}\% \text { of } \\
\text { total } \\
\text { billion } \\
\text { rubles }\end{array}$ & $\begin{array}{l}\text { billion } \\
\text { rubles }\end{array}$ & $\begin{array}{l}\text { \% of } \\
\text { total }\end{array}$ \\
\hline $\begin{array}{l}\text { Property } \\
\text { insurance }\end{array}$ & 701.14 & 95.8 & 666.46 & 94.93 & 685.34 & 94.0 \\
\hline $\begin{array}{l}\text { Insurance } \\
\text { of business } \\
\text { risks }\end{array}$ & 8.90 & 1.2 & 9.05 & 1.3 & 10.49 & 1.4 \\
\hline $\begin{array}{l}\text { Insurance } \\
\text { of financial } \\
\text { risks }\end{array}$ & 21.23 & 2.93 & 26.54 & 3.78 & 33.10 & 4.5 \\
\hline
\end{tabular}

Premiums for insurance of financial risks increased for the analyzed period by $36 \%$ compared to 2016 , this is due to the insurance of Bank cards. In total during the analyzed period, insurers concluded an average of 5.8 million contracts. The leader of the insurance market in terms of premiums collected is property insurance although, premiums have declined over the past two years.

TABLE II. VOLUME OF INSURANCE PAYMENTS FOR 2016-2018 [9]

\begin{tabular}{|l|l|l|l|l|l|l|}
\hline \multirow{2}{*}{$\begin{array}{c}\text { Types of } \\
\text { insurance }\end{array}$} & $\begin{array}{l}\text { billion } \\
\text { rubles }\end{array}$ & $\begin{array}{c}\text { \% of } \\
\text { total } \\
\text { billion } \\
\text { rubles }\end{array}$ & $\begin{array}{c}\text { billion } \\
\text { rubles }\end{array}$ & $\begin{array}{c}\text { \% of } \\
\text { total } \\
\text { billion } \\
\text { rubles }\end{array}$ & $\begin{array}{l}\text { billion } \\
\text { rubles }\end{array}$ & $\begin{array}{c}\text { \% of } \\
\text { total }\end{array}$ \\
\hline $\begin{array}{l}\text { Types of } \\
\text { insurance }\end{array}$ & 344.89 & 95.62 & 336.36 & 96.12 & 315.01 & 96.5 \\
\hline $\begin{array}{l}\text { Property } \\
\text { insurance }\end{array}$ & 13.95 & 3.37 & 11.23 & 3.21 & 8.86 & 2.7 \\
\hline $\begin{array}{l}\text { Insurance } \\
\text { of business } \\
\text { risks }\end{array}$ & 1.85 & 0.51 & 2.35 & 0.67 & 2.50 & 0.8 \\
\hline \multicolumn{7}{|c|}{ b. Source: calculated by the authors on the basis of data from the Russian Bank } \\
http://www.cbr.ru/statistics/?PrtId=pdko_sub
\end{tabular}

Payments for insurance of financial risks for the analyzed period amounted to an average of 2.2 billion rubles. We can see that payments as well as premiums, increased in 2018 for this type of insurance. In 2018, 62.406 thousands and 58.933 thousands insurance claims were reported to insurers.

It should be noticed that in the study of large and mediumsized businesses, it was revealed that large enterprises are insured, avoiding gray "salary" schemes, seeking to enter into contracts of real insurance, covering a large amount of various risks [10].

However, big business sees insurance as an effective method of protection against risks. Medium-sized enterprises do not have full insurance coverage [11]. The average business in General, forced to insure only the risks associated with hazardous production [12]. 
support includes marketing, financial, Advisory, management, technical, and infrastructure support [25].

\section{CONCLUSION}

The following conclusions based on the above analysis were made: insurance of industrial enterprises financial risks is still poorly developed in Russia. Insurance for this type is in low demand, as evidenced by the small amount of insurance premiums received by insurance companies, although there is a positive dynamics of the development of this insurance market. At the same time, the prospects for the development of this market are difficult to predict, as they largely depend on the state of the country's economy and on the level of its development.

\section{REFERENCES}

[1] L. H. Kurbanova, "Methods of assessment of financial risks", Integration processes in science in modern conditions: collection of articles of the International scientific and practical conference, In 2ch, Part 1, Ufa: RIO M-OMEGA SCIENCES, 2015, pp. 116-119.

The necessary conditions for solving these problems are:

- first, to improve the legislative framework in this area, expand and deepen the legal framework governing the insurance of financial risks of industrial enterprises;

- second, raising the public awareness about the insurance products of this insurance industry;

- third, a clear definition of key insurance concepts, the adoption of standard insurance rules in this area.

Based on the research of economists [18-20], we can say that in their activities, insurance companies should strive for an optimal combination of the proportion between risk acceptance and capital. To minimize risks, property liability insurance companies resort to reinsurance. These measures will increase the rating of the insurer's financial stability. In addition, using an extreme approach to modeling losses from operational risk can significantly increase the expected increase in wealth from insurance.

Compulsory insurance raises all consumers' welfare only in adverse selection, but not in other equilibrium patterns [21].

However, we must not forget that insurers are sensitive to the risk of volatility (the risk of losses when volatility increases), but not to insurance risks, financial industry risks, liquidity risk or stagnation after controlling other General economic factors [22]. We believe it is legitimate to attach importance to the structure of insurance schemes when insurers face several insurance risks in the process of insuring the enterprise and the risk of adverse selection increases [23]. This can be done in the form of contracts that involve a specific risk, or contracts that combine risks.

In the insurance market, it is necessary to ensure market conditions, avoid monopolies, try to minimize heterogeneous beliefs and reduce the level of imperfect information on insurance areas [24]. In our opinion, it is very important to have the support of the government to solve the tasks set. This
[2] N. V. Khokhlov, "Risk Management", Moscow: unity-Dana, 2017, 239 $\mathrm{p}$

[3] E. V. Karanina, "Financial risk Management: strategic concepts, models, professional standards: studies", Benefit. Kirov: vyatgu Publishing house, 2015, 217 p. ISBN 978-5-7410-1565-0.

[4] N. V. Nemtsova, "Formation of insurance protection system at industria

[5] T. Y. Anopchenko, I. A. Pryadko, K. T. Paytaeva, O. S. Dubskaya, and A. D. Murzin, "Organizational Model of Regional Socio-Economic Territorial Management", International Journal of Economics and Financial Issues, 2015, 5 (4), pp.1066-1074.

[6] "Civil code of the Russian Federation", Consultant Plus [Electronic resource]. Available at: http://www.consultant.ru.

[7] L. M. Sadykova, "Insurance market of Russia: state and prospects of development" [Electronic resource]: monograph, M-in education and science ROS. Federations, Feder. State budget. Educated. Establishment of the University. Education, Orenburg. GOS. UN-t, Orenburg: OSU.

[8] T. Mihova and V. Nikolova-Alexieva, "Risk management in industrial enterprises", scientific proceedings xi international congress "Machines, technologies, materials", 2014, XXII, vol. 4, pp. 52-55.

[9] Insurance today [Electronic resource]. Available at: http://www.insurinfo.ru.

[10] Yu. Z. Drachuk, N. I. Novikova, and N. V. Trushkina, "Institutional economic security of industrial enterprise", Economic Bulletin of

[11] Y. Yang, J. G. Lin , and Z. Q. Tan, "The finite-time ruin probability in the presence of sarmanov dependent financial and insurance risks", Applied mathematics a journal of chinese universities, Series B, 2014, 29, no. 2, pp.194-204.

[12] Y. Chen and Z. Yuan, "A revisit to ruin probabilities in the presence of heavy-tailed insurance and financial risks", Insurance: mathematics and economics, 2017, 73, pp. 75-81.

[13] O. N. Uglitskikh and T.S. Donchenko, "Financial risks insurance company", Results of modern scientific research, Astana, Kazakhstan, 2017, pp.140-144.

[14] Y. Chen, "Interplay of subexponential and dependent insurance and financial risks", Insurance: mathematics and economics, 2017, 77, pp.78-83.

[15] F. M. Al Rawashdeh and O. Al Singlawi, "The Existence of Fraud Indicators in Insurance Industry: Case of Jordan", International Journal of Economics and Financial Issues, 2016, vol. 6, no. 6s, pp.168-176. enterprises", Mechanical engineering and computer technologies, 2017. Donbass, 2014, no. 3 (37), pp. 112-120. 
[20] Glenn W. Harrison and Jia Min Ng, "Evaluating the Expected Welfare Gain From Insurance", The Journal of Risk and Insurance, 2016, vol. 83, no. 1, pp. 91-120 [Electronic resource]. Available at: www.jstor.org/stable/43998254 (Accessed: 16 January 2020).

[21] "Self-Control, Effort Procrastination, and Competitive Equilibrium in Insurance Markets", The Journal of Risk and Insurance, 2019, vol. 86 , issue 1 .

[22] "Estimating the Cost of Equity Capital for Insurance Firms With Multiperiod Asset Pricing Models", The Journal of Risk and Insurance, 2019, vol. 86, issue 1.

[23] P. Picard, "Splitting Risks in Insurance Markets With Adverse Selection", The Journal of Risk and Insurance, 2019, vol. 86, issue 1.

[24] M. M. Ogaku, "Heterogeneous Beliefs and Imperfect Information: The Insurance Market", The Official Journal of the Asia-Pacific Risk and Insurance Association, January 2020, vol. 14, issue 1.

[25] M. Ali Alqassabi, "Insights on sustainability of small and medium enterprises in oman: a conceptual framework", International Journal of Economics and Financial Issues, 2020, vol. 10, no. 1, pp. 209-218. 